\title{
Preparation of optically active bicyclodihydrosiloles by a radical cascade reaction
}

\author{
Koichiro Miyazaki ${ }^{1}$, Yu Yamane ${ }^{1}$, Ryuichiro Yo ${ }^{1}$, Hidemitsu Uno ${ }^{2}$ \\ and Akio Kamimura*1
}

Open Access

\author{
Full Research Paper \\ Address: \\ ${ }^{1}$ Department of Applied Molecular Bioscience, Graduate School of \\ Medicine, Yamaguchi University, Ube 755-8611, Japan and \\ 2Department of Chemistry, Graduate School of Science and \\ Engineering, Ehime University, Matsuyama, 790-8577, Japan \\ Email: \\ Akio Kamimura* - ak10@yamaguchi-u.ac.jp \\ * Corresponding author \\ Keywords: \\ bicyclodihydrosilole; free radical; radical cascade reaction; $\mathrm{S}_{\mathrm{H}} \mathrm{i}$ \\ reaction; tris(trimethylsilyl)silane
}

\author{
Beilstein J. Org. Chem. 2013, 9, 1326-1332. \\ doi:10.3762/bjoc. 9.149 \\ Received: 27 April 2013 \\ Accepted: 18 June 2013 \\ Published: 04 July 2013 \\ This article is part of the Thematic Series "Organic free radical chemistry". \\ Guest Editor: C. Stephenson \\ (c) 2013 Miyazaki et al; licensee Beilstein-Institut. \\ License and terms: see end of document.
}

\begin{abstract}
Bicyclodihydrosiloles were readily prepared from optically active enyne compounds by a radical cascade reaction triggered by tris(trimethylsilyl)silane $\left(\left(\mathrm{Me}_{3} \mathrm{Si}\right)_{3} \mathrm{SiH}\right)$. The reaction was initiated by the addition of a silyl radical to an $\alpha, \beta$-unsaturated ester, forming an $\alpha$-carbonyl radical that underwent radical cyclization to a terminal alkyne unit. The resulting vinyl radical attacked the silicon atom in an $\mathrm{S}_{\mathrm{H}} \mathrm{i}$ manner to give dihydrosilole. The reaction preferentially formed trans isomers of bicyclosiloles with an approximately $7: 3$ to $9: 1$ selectivity.
\end{abstract}

\section{Introduction}

Radical cyclization occupies a unique position in organic synthesis because it is a useful reaction for the construction of cyclic molecules [1-10]. The radical cascade cyclization process is also an interesting synthetic reaction that often provides an efficient method [11-13]. Recently, we reported a new type of higher-order radical cascade reaction between chiral enyne compounds and $\mathrm{Bu}_{3} \mathrm{SnH}$, which is recognized as a useful reagent in radical reactions [14]. In this reaction, radical addition-cyclization cascade followed by intramolecular radical substitution $\left(\mathrm{S}_{\mathrm{H}} \mathrm{i}\right)$ occurred in one-pot to give optically active bicyclostannolanes in good yields [15]. We are interested in whether such a cascade $\mathrm{S}_{\mathrm{H}} \mathrm{i}$ process might occur with other radical species. We have found that a methylthiyl radical also undergoes such a radical cascade reaction to stereoselectively give bicyclic dihydrothiophenes [16]. We expected that tris(trimethylsilyl)silane $\left(\mathrm{Me}_{3} \mathrm{Si}\right)_{3} \mathrm{SiH}$ [17], which is a wellknown alternative to $\mathrm{Bu}_{3} \mathrm{SnH}$ in radical reactions [18-22], would be a good promoter of a similar cascade $\mathrm{S}_{\mathrm{H}}$ i reaction, because there were several reports so far that show such $\mathrm{S}_{\mathrm{H}} \mathrm{i}$ reaction on silicon atoms progressing efficiently [23-28]. In this 
paper, we report a new synthesis of chiral bicyclodihydrosiloles through an addition-cyclization- $\mathrm{S}_{\mathrm{H}} \mathrm{i}$ cascade reaction in onepot treatment of chiral enyne compounds. A good trans-selectivity was observed in the reaction.

\section{Results and Discussion}

We examined the cascade process using optically active enyne precursor 1a, which was prepared by a Michael/aldol domino reaction to chiral sulfinimines followed by thermal elimination and $N$-propargylation $[29,30]$. We first optimized the reaction conditions. The results are summarized in Table 1.

Treatment of 1 with $\left(\mathrm{Me}_{3} \mathrm{Si}\right)_{3} \mathrm{SiH}$ in the presence of catalytic amounts of AIBN at $110{ }^{\circ} \mathrm{C}$ resulted in the formation of the desired bicyclodihydrosilole 2a in 14\% yield (Table 1, entry 1). The use of one equivalent of AIBN improved the yield of $2 \mathbf{a}$ to $39 \%$ (Table 1, entry 2). These results suggest that the radical chain reaction insufficiently progressed during the reaction initiated by AIBN. The product contained two diastereomers, which were separated by chromatography. The use of $\mathrm{Et}_{3} \mathrm{~B} / \mathrm{air}$ as an initiator enhanced the yield of $2 \mathbf{a}$ to $58 \%$ (Table 1, entry 3 ). The enantiomeric excess of trans-2a was estimated to be $95 \%$ by HPLC analysis, which was the same ee level of precursor 1a. Thus, no epimerization at the $\mathrm{C} 3$ chiral center occurred during the reaction. The stereoselectivity was improved to $8: 2$. The stereoselectivity was sensitive to the reaction temperature, and an 86/14 mixture of trans-2a and cis-2a was obtained when the reaction was performed at $0{ }^{\circ} \mathrm{C}$, although the yield was less than that obtained when the reaction was performed at room temperature (Table 1, entry 4).

Having determined the optimized reaction conditions, we examined the generality of the reaction. The results are summarized in Table 2.
For example, the reaction of $\mathbf{1 b}$ smoothly occurred, giving bicyclic dihydrosilole $\mathbf{2 b}$ in $60 \%$ yield. HPLC analysis of the reaction mixture revealed that the diastereomeric ratio of $\mathbf{2 b}$ was $84 / 16$. Dihydrosiloles $\mathbf{2} \mathbf{c}-\mathbf{2} \mathbf{j}$ were isolated in good yields from other precursors in a trans-selective manner (Table 2, entries 2-9). Their diastereomeric ratios ranged from $9 / 1$ to $7 / 3$. Although we could not determine the enantiomeric excesses for some compounds of $\mathbf{2}$ because of insufficient separation by chiral HPLC analyses using ChiralPak ID and IC (Table 2, entries 1,2, and 4), the enantiomeric excesses of most of products 2 were high, and their original values were maintained (Table 2 , entries $3,5,6,8$, and 9). Interestingly, significant epimerization occurred during the reaction of $\mathbf{1 h}$; the enantiomeric excess of $\mathbf{2 h}$ was only $68 \%$ ee (Table 2 , entry 7 ).

The configuration of $\mathbf{2}$ was determined in the following manner: The major isomer of $\mathbf{2 a}$ was highly crystalline, which allowed the performance of X-ray crystallography. The observed data clearly showed a trans- 2a structure [31]. The ORTEP structure of major 2a, which unambiguously indicates a trans configuration, is shown in Figure 1. The ${ }^{1} \mathrm{H}$ NMR spectra of trans-2a and other major $\mathbf{2}$ showed similar trends, and trans configurations for other major $\mathbf{2}$ were determined unambiguously.

Unfortunately, none of the minor $\mathbf{2}$ formed suitable crystals, which precluded X-ray analysis of the minor isomers. However, their ${ }^{1} \mathrm{H}$ NMR spectra showed several diagnostic points. For example, the tert-butyl group in the ester at the $\mathrm{C} 3 \mathrm{a}$ position in minor 2a appeared at $1.17 \mathrm{ppm}$; this peak was substantially shifted toward higher field than trans-2a. Compared with X-ray data for the sulfur analogue of cis-2a, the tert-butyl ester group is located above the aromatic ring at $\mathrm{C} 3$, and expected to introduce an anisotropic effect that subsequently causes a high-field

Table 1: Radical cascade reaction under various reaction conditions.

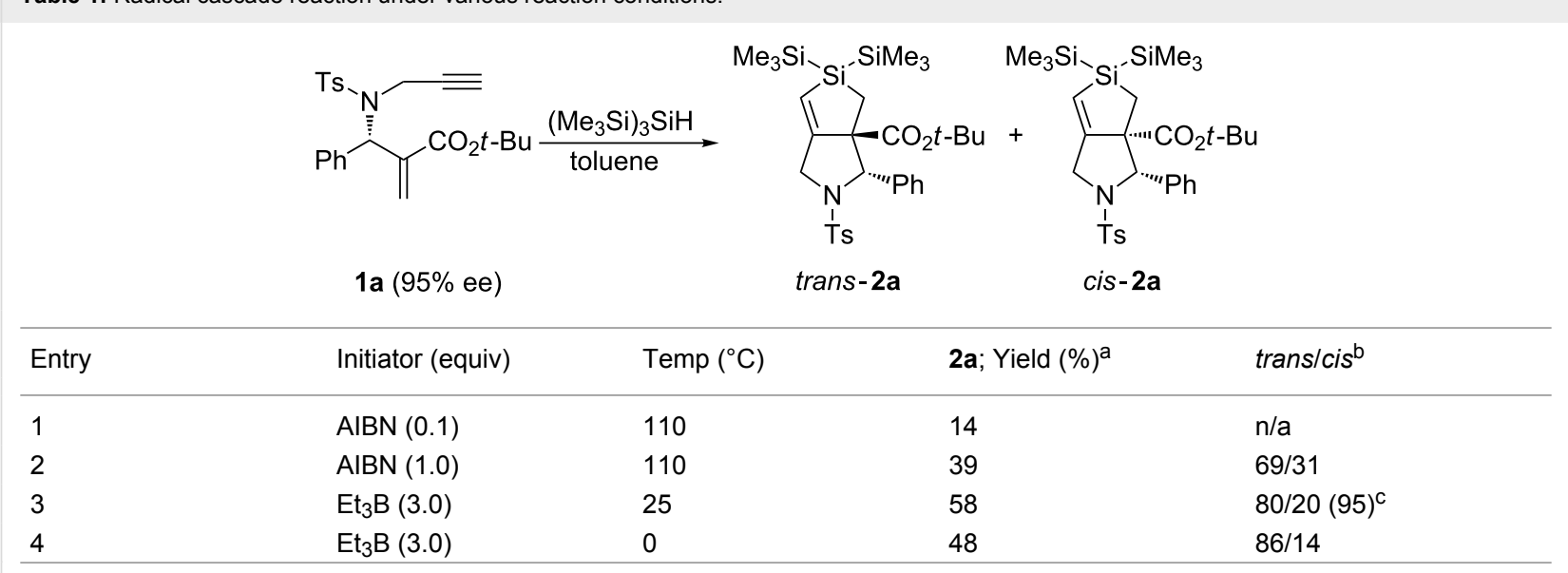

alsolated yield. ${ }^{b}$ Determined by HPLC analyses. ${ }^{\mathrm{C}}$ Enantiomeric excess for trans-2a. Determined by chiral HPLC analysis using ChiralPak ID. 
Table 2: Preparation of pyrrolidinodihydrosiloles 2.

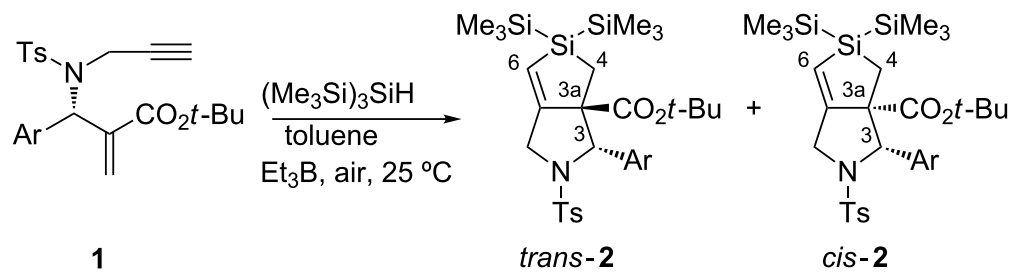

\begin{tabular}{|c|c|c|c|c|c|}
\hline Entry & $\mathrm{Ar}$ & Product & Yielda $^{a}(\%)$ & trans/cis ${ }^{b}$ & ee for trans-2 \\
\hline 1 & $2-\mathrm{MeC}_{6} \mathrm{H}_{4}$ & $2 b$ & 60 & $84 / 16$ & $n d^{d}$ \\
\hline 2 & $4-\mathrm{MeC}_{6} \mathrm{H}_{4}$ & $2 c$ & 53 & $91 / 9$ & $n d^{d}$ \\
\hline 3 & $4-\mathrm{MeOC}_{6} \mathrm{H}_{4}$ & $2 d$ & 42 & $86 / 14$ & 97 \\
\hline 4 & $3-\mathrm{ClC}_{6} \mathrm{H}_{4}$ & $2 e$ & 42 & $71 / 29$ & $n d^{d}$ \\
\hline 5 & $4-\mathrm{ClC}_{6} \mathrm{H}_{4}$ & $2 f$ & 51 & $81 / 19$ & 90 \\
\hline 6 & $4-\mathrm{FC}_{6} \mathrm{H}_{4}$ & $2 g$ & 61 & $80 / 20$ & 97 \\
\hline 7 & $4-\mathrm{CF}_{3} \mathrm{C}_{6} \mathrm{H}_{4}$ & $2 \mathrm{~h}$ & 61 & $80 / 20$ & 68 \\
\hline 8 & 2-thienyl & $2 \mathbf{i}$ & 48 & $75 / 25$ & 98 \\
\hline 9 & 2-naphthyl & $2 j$ & 51 & $81 / 19$ & 99 \\
\hline
\end{tabular}

${ }^{a}$ Isolated yield. ${ }^{b}$ Determined by HPLC analyses. ${ }^{c}$ Determined by HPLC analyses with a Chiral-Pak-ID. ${ }^{d}$ Not determined owing to insufficient separation by chiral HPLC analyses with ChiralPak ID and IC.

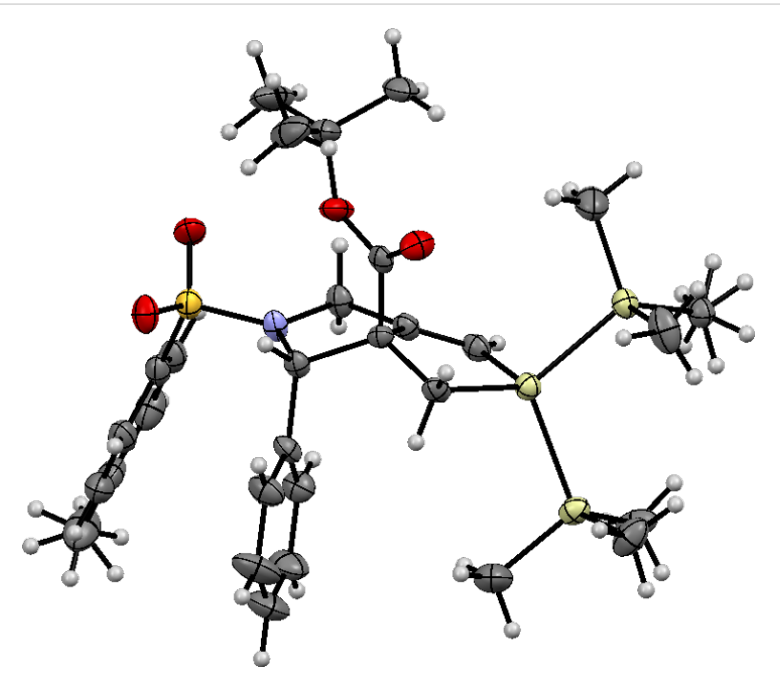

Figure 1: ORTEP structure of trans-2a. shift for the tert-butyl protons [28]. Other typical differences between the ${ }^{1} \mathrm{H}$ NMR spectra of minor $\mathbf{2 a}$ and major $\mathbf{2 a}$ (= trans-2a) included the following: The peaks of the $\mathrm{CH}_{2} \mathrm{Si}$ group at the $\mathrm{C} 4$ position in minor $2 \mathrm{a}$ appeared at 0.92 and $2.00 \mathrm{ppm}$, whereas the corresponding peaks of trans-2a were observed at 0.49 and $1.14 \mathrm{ppm}$. In addition, we found that H6 and H3 appeared at 5.51 and $4.46 \mathrm{ppm}$, respectively, in the spectrum of minor 2a. The corresponding protons in trans-2a appeared at substantially lower-field positions at 5.86 and $5.53 \mathrm{ppm}$. We assumed that this shift was caused by another anisotropic effect of the Ts group at N2. These trends in the ${ }^{1} \mathrm{H}$ NMR spectra were also observed in the sulfur analogues of cis-2. Thus, we concluded that the minor isomer of $\mathbf{2}$ exhibited cis configuration.

To explore the reaction mechanism, we examined the reaction of 1a without additional solvents (Scheme 1).



Scheme 1: Formation of bicyclic dihydrosilole $2 \mathbf{a}$ under high concentration conditions. 


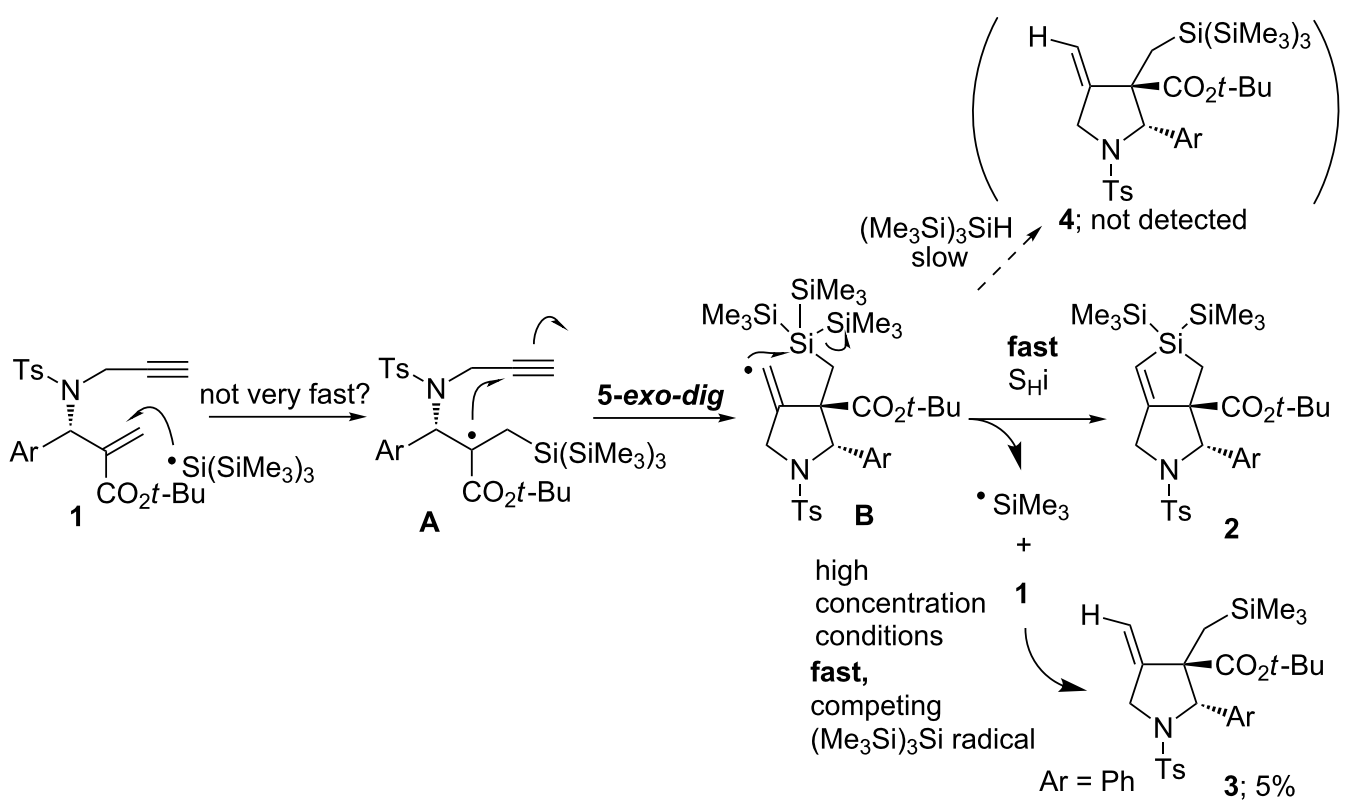

Scheme 2: Plausible reaction mechanism.

The treatment of $1 \mathrm{a},\left(\mathrm{Me}_{3} \mathrm{Si}\right)_{3} \mathrm{SiH}$, and $\mathrm{Et}_{3} \mathrm{~B}$ in hexane under an air atmosphere gave $\mathbf{2 a}$ in $72 \%$. To our surprise, this yield was better than that of the reaction performed under the usual conditions. We expected that exo-methylenepyrrolidine 4 would be a side product under these conditions, and we indeed detected an exo-methylene compound in 5\% yield in the reaction mixture. However, NMR spectra and HRMS results indicated that the isolated product was compound $\mathbf{3}$, which contained a $\mathrm{Me}_{3} \mathrm{SiCH}_{2}$ - group instead of a $\left(\mathrm{Me}_{3} \mathrm{Si}\right)_{3} \mathrm{SiCH}_{2}$ - group. These results suggest that $\mathrm{Me}_{3} \mathrm{Si}$ radicals were generated during the cascade reaction, and that a small part of the radical was subsequently trapped by $\mathbf{1}$ under such conditions.

We believe this process progressed in a similar manner to our previously investigated reaction that involved tributyltin radicals [15]. A plausible reaction mechanism is depicted in Scheme 2 .

The $\left(\mathrm{Me}_{3} \mathrm{Si}\right)_{3} \mathrm{Si}$ radical attacks the $\beta$-carbon of the $\alpha, \beta$-unsaturated ester in $\mathbf{1}$, and $\alpha$-carbonyl radical $\mathbf{A}$ is generated. Intermediate $\mathbf{A}$ undergoes radical cyclization in a 5-exo-dig mode giving vinyl radical intermediate $\mathbf{B}$, which is potentially reactive for attacking the silyl group in an $\mathrm{S}_{\mathrm{H}} \mathrm{i}$ manner to give a $\mathrm{Me}_{3} \mathrm{Si}$ radical and $\mathbf{2}$. The process from $\mathbf{B}$ to $\mathbf{2}$ should be very rapid. Giese and co-workers have reported that the reaction rate for a similar $\mathrm{S}_{\mathrm{H}} \mathrm{i}$ process reaches $2.4 \times 10^{5} \mathrm{~s}^{-1}$ at $80{ }^{\circ} \mathrm{C}$ [25]. Although most of the $\mathrm{Me}_{3} \mathrm{Si}$ radicals undergo hydrogen abstraction from $\left(\mathrm{Me}_{3} \mathrm{Si}\right)_{3} \mathrm{SiH}$ to yield a new $\left(\mathrm{Me}_{3} \mathrm{Si}\right)_{3} \mathrm{Si}$ radical and $\mathrm{Me}_{3} \mathrm{SiH}$, a small fraction of the $\mathrm{Me}_{3} \mathrm{Si}$ radicals compete to attack 1; a similar cascade reaction progresses consequently, and compound $\mathbf{3}$ is formed in 5\% yield under very high concentration conditions. We assume that compound 4 was not detected in the reaction product under such conditions for two reasons: first, as previously mentioned, the $\mathrm{S}_{\mathrm{H}} \mathrm{i}$ process from intermediate $\mathbf{B}$ to $\mathbf{2}$ is very rapid, and the process occurs faster than intermolecular hydrogen abstraction from $\left(\mathrm{Me}_{3} \mathrm{Si}\right)_{3} \mathrm{SiH}$, even under high concentration conditions. Second, the addition rate of $\left(\mathrm{Me}_{3} \mathrm{Si}\right)_{3} \mathrm{Si}$ radicals to alkenes should be relatively slow; the rate competes with the addition rate of $\mathrm{Me}_{3} \mathrm{Si}$ radicals to alkenes. This reason is supported by the results that indicated the yield of $2 \mathbf{a}$ to be much improved under high $\left(\mathrm{Me}_{3} \mathrm{Si}\right)_{3} \mathrm{SiH}$ concentration conditions because the addition rate should be accelerated as the concentration of $\left(\mathrm{Me}_{3} \mathrm{Si}\right)_{3} \mathrm{SiH}$ increased.

We examined whether a germyl radical might undergo a similar reaction with $\mathbf{1}$. Treatment of $\mathbf{1}$ with $\mathrm{Et}_{3} \mathrm{GeH}$ in the presence of $\mathrm{Et}_{3} \mathrm{~B}$, however, failed in the formation of the corresponding compound 5. This failure was probably because a carbon-germanium bond, which is supposed to be stronger than a $\mathrm{Si}-\mathrm{Si}$ bond, was never cleaved under these conditions (Scheme 3). Another possibility of this failure might be that the addition rate of a triethylgermyl radical to enyne 1a was slow and less efficient.

\section{Conclusion}

In conclusion, we have successfully converted chiral enyne compounds $\mathbf{1}$, which were readily available from an asymmetric aza-Morita-Baylis-Hillman equivalent reaction, into 




bicyclic pyrolidinodihydrosiloles $\mathbf{2}$ in good yields. These reactions progressed in a highly stereoselective manner. Further application of the present silole synthesis is now underway in our laboratory.

\section{Experimental}

General methods: $\mathrm{All}{ }^{1} \mathrm{H}$ and ${ }^{13} \mathrm{C}$ NMR spectra were recorded on a JEOL JNM-ECA500 Delta2 $\left(500 \mathrm{MHz}\right.$ for ${ }^{1} \mathrm{H}, 126 \mathrm{MHz}$ for ${ }^{13} \mathrm{C}$ ) spectrometer. All the reactions in this study were performed under nitrogen atmosphere unless otherwise noted. $\mathrm{CH}_{2} \mathrm{Cl}_{2}$ was dried over $\mathrm{CaH}_{2}$, and distilled under nitrogen before use. High-resolution mass spectra (HRMS) were measured at the Tokiwa Instrumentation Analysis Center, Yamaguchi University.

Preparation of (3S)-tert-butyl 3-phenyl-2-tosyl-5,5bis(trimethylsilyl)-1,2,3,3a,4,5-hexahydrosilolo $[3,4-$ c)pyrrole-3a-carboxylate (2a). A solution of $\mathbf{1 a}(85 \mathrm{mg}$, $0.201 \mathrm{mmol}, 95 \%$ ee $),\left(\mathrm{Me}_{3} \mathrm{Si}\right)_{3} \mathrm{SiH}(0.06 \mathrm{~mL}, 0.195 \mathrm{mmol})$, and $\mathrm{Et}_{3} \mathrm{~B}(1.0 \mathrm{M}$ in hexane, $0.60 \mathrm{~mL}, 0.60 \mathrm{mmol})$ in toluene $(20 \mathrm{~mL})$ was stirred at room temperature under air for $15 \mathrm{~min}$. The reaction mixture was concentrated in vacuo, and the residue was purified by flash chromatography (silica gel/hexane-EtOAc $15 / 1$ to $10 / 1, \mathrm{v} / \mathrm{v})$ to give 2 a in $58 \%$ yield $(70.2 \mathrm{mg}$, $0.117 \mathrm{mmol}$ ). The two diastereomers, trans-2a and cis-2a, were separated by further careful chromatography.

(3S,3aS)-tert-Butyl 3-phenyl-2-tosyl-5,5-bis(trimethylsilyl)1,2,3,3a,4,5-hexahydrosilolo $[3,4-c]$ pyrrole-3a-carboxylate (trans-2a). White solid; mp $144-145{ }^{\circ} \mathrm{C} ;[\alpha]_{\mathrm{D}}-31.8$ (c 0.68 , $\mathrm{CHCl}_{3}$ ); the enantiomeric purity was determined by HPLC analysis, $t_{\mathrm{R}} 10.0 \mathrm{~min}$ (major), $t_{\mathrm{R}} 11.5 \mathrm{~min}$ (minor) [CHIRALPAK ID $(0.46 \mathrm{~cm} \times 25 \mathrm{~cm})$, hexane/iPrOH, $95 / 5$, $\left.40{ }^{\circ} \mathrm{C}, 1.0 \mathrm{~mL} / \mathrm{min}\right]$ to be $95 \%$ ee; ${ }^{1} \mathrm{H} \mathrm{NMR}\left(500 \mathrm{MHz}, \mathrm{CHCl}_{3}\right)$ $\delta 7.32(\mathrm{~d}, J=8.2 \mathrm{~Hz}, 2 \mathrm{H}), 7.26$ (s, 3H), 7.24-7.07 (m, 2H), 7.03 $(\mathrm{d}, J=7.8 \mathrm{~Hz}, 2 \mathrm{H}), 5.86(\mathrm{~s}, 1 \mathrm{H}), 5.23(\mathrm{~s}, 1 \mathrm{H}), 4.42(\mathrm{~d}, J=$ $13.0 \mathrm{~Hz}, 1 \mathrm{H}), 3.95(\mathrm{~d}, J=13.0 \mathrm{~Hz}, 1 \mathrm{H}), 2.32(\mathrm{~s}, 3 \mathrm{H}), 1.51(\mathrm{~s}$ 9H), $1.15(\mathrm{~d}, J=14.9 \mathrm{~Hz}, 1 \mathrm{H}), 0.50(\mathrm{~d}, J=14.8 \mathrm{~Hz}, 1 \mathrm{H}), 0.07$ $(\mathrm{s}, 9 \mathrm{H}),-0.20(\mathrm{~s}, 9 \mathrm{H}) ;{ }^{13} \mathrm{C} \mathrm{NMR}\left(126 \mathrm{MHz}, \mathrm{CHCl}_{3}\right) \delta 173.9$, 157.6, 142.6, 138.6, 137.1, 129.1 (2C), 128.3 (br, 4C), 127.5,
$127.0(2 \mathrm{C}), 124.2,82.3,71.1,69.7,50.5,28.0$ (3C), 21.5, 12.2, -0.3 (3C), -0.9 (3C); HRMS-ESI (positive mode; $\mathrm{M}+\mathrm{Na}$ ) $\mathrm{m} / \mathrm{z}$ 622.2282, calcd for $\mathrm{C}_{30} \mathrm{H}_{45} \mathrm{NNaO}_{4} \mathrm{SSi}_{3}, 622.2275$.

(3S,3aR)-tert-Butyl 3-phenyl-2-tosyl-5,5-bis(trimethylsilyl)1,2,3,3a,4,5-hexahydrosilolo[3,4-c]pyrrole-3a-carboxylate (cis-2a). Pale yellow oil; $[\alpha]_{\mathrm{D}}+97.3\left(\mathrm{c} 0.27, \mathrm{CHCl}_{3}\right) ;{ }^{1} \mathrm{H} \mathrm{NMR}$ $\left(500 \mathrm{MHz} \mathrm{CHCl}_{3}\right) \delta 7.63(\mathrm{~d}, J=7.8 \mathrm{~Hz}, 2 \mathrm{H}), 7.57-7.50(\mathrm{~m}$, $2 \mathrm{H}), 7.33-7.22(\mathrm{~m}, 5 \mathrm{H}), 5.51(\mathrm{~s}, 1 \mathrm{H}), 4.60(\mathrm{~d}, J=14.3 \mathrm{~Hz}, 1 \mathrm{H})$, $4.23(\mathrm{~s}, 1 \mathrm{H}), 4.11(\mathrm{dd}, J=14.3,1.6 \mathrm{~Hz}, 1 \mathrm{H}), 2.39$ (s, 3H), 2.00 (d, $J=12.8 \mathrm{~Hz}, 1 \mathrm{H}), 1.17$ (s, 9H), $0.92(\mathrm{~d}, J=15.0 \mathrm{~Hz}, 1 \mathrm{H})$, $0.04(\mathrm{~s}, 9 \mathrm{H}),-0.11(\mathrm{~s}, 9 \mathrm{H}) ;{ }^{13} \mathrm{C} \mathrm{NMR}\left(126 \mathrm{MHz}, \mathrm{CHCl}_{3}\right) \delta$ $169.5,157.8,143.8,138.1,133.1,129.9$ (2C), $128.0(2 \mathrm{C}), 127.7$ (2C), 127.7, 127.1 (br, 2C), 122.8, 82.1, 75.2, 72.5, 53.7, 27.9 (3C), 21.6, 17.4, 0.3 (3C), -1.4 (3C); HRMS-ESI (positive mode; $\mathrm{M}+\mathrm{Na}$ ) $\mathrm{m} / z$ 622.2292, calcd for $\mathrm{C}_{30} \mathrm{H}_{45} \mathrm{NNaO}_{4} \mathrm{SSi}_{3}$, 622.2275 .

Preparation of 2 a under no solvent conditions (Scheme 3, neat condition). A solution of $\mathbf{1 a}(85 \mathrm{mg}, 0.201 \mathrm{mmol})$, $\left(\mathrm{Me}_{3} \mathrm{Si}\right)_{3} \mathrm{SiH}(0.07 \mathrm{~mL}, 0.228 \mathrm{mmol})$, and $\mathrm{Et}_{3} \mathrm{~B}(1.0 \mathrm{M}$ in hexane, $0.60 \mathrm{~mL}, 0.60 \mathrm{mmol}$ ) was stirred at room temperature for 15 min under air. The reaction mixture was concentrated in vacuo, and the yellow residue was purified by flash chromatography (silica gel/hexane-EtOAc 30/1 to $20 / 1 \mathrm{v} / \mathrm{v}$ ) to give 2a in $72 \%$ yield $(85.6 \mathrm{mg}, 0.143 \mathrm{mmol}$ ). The trans-2a/cis-2a ratio was determined to be $84 / 16$. Careful separation of these two diastereomers gave pure trans-2a and minor isomers that contained cis-2a and $\mathbf{3}$ in a 74/26 ratio. The separation of $\mathbf{3}$ was achieved using a recycling GPC apparatus, giving pure 3 in 5\% yield (5.1 mg, $0.011 \mathrm{mmol})$.

(2S,3S)-tert-Butyl 3-((trimethylsilyl)methyl)-4-methylene-2phenyl-1-tosylpyrrolidine-3-carboxylate (3). Pale yellow oil; $[\alpha]_{\mathrm{D}}+3.0\left(\mathrm{c} 0.01, \mathrm{CHCl}_{3}\right) ;{ }^{1} \mathrm{H} \mathrm{NMR}\left(500 \mathrm{MHz}, \mathrm{CHCl}_{3}\right) \delta$ 7.20-7.09 (m, 5H), 7.00-6.94 (m, 4H), $5.36(\mathrm{~s}, 1 \mathrm{H}), 5.21(\mathrm{t}, J=$ $1.8 \mathrm{~Hz}, 1 \mathrm{H}), 5.14(\mathrm{dd}, J=2.7,1.5 \mathrm{~Hz}, 1 \mathrm{H}), 4.36(\mathrm{dt}, J=13.0$, $2.5 \mathrm{~Hz}, 1 \mathrm{H}), 3.90(\mathrm{dt}, J=13.0,1.5 \mathrm{~Hz}, 1 \mathrm{H}), 2.29$ (s, 3H), 1.50 (s, 9H), $0.90(\mathrm{~d}, J=14.6 \mathrm{~Hz}, 1 \mathrm{H}), 0.48(\mathrm{~d}, J=14.7 \mathrm{~Hz}, 1 \mathrm{H})$, -0.13 (s, 9H); ${ }^{13} \mathrm{C}$ NMR (126 MHz, $\left.\mathrm{CHCl}_{3}\right) \delta 172.4,148.8$, 
142.4, 138.2, 136.7, 129.0 (4C), 128.1 (2C), 127.8, 127.0 (2C), 110.0, 82.4, 70.2, 61.0, 51.5, 27.9 (3C), 21.5, 19.6, 0.7 (3C); HRMS-ESI (positive mode; $\mathrm{M}+\mathrm{Na}$ ) $\mathrm{m} / z$ 522.2108, calcd for $\mathrm{C}_{27} \mathrm{H}_{37} \mathrm{NNaO}_{4} \mathrm{SSi}$, 522.2110.

\section{Supporting Information}

\section{Supporting Information File 1}

Experimental procedures and ${ }^{1} \mathrm{H}$ and ${ }^{13} \mathrm{C}$ NMR spectra. [http://www.beilstein-journals.org/bjoc/content/ supplementary/1860-5397-9-149-S1.pdf]

\section{Supporting Information File 2}

CIF data for trans-2a.

[http://www.beilstein-journals.org/bjoc/content/

supplementary/1860-5397-9-149-S2.cif]

\section{Acknowledgements}

We are grateful to financial assistance from the Sasakawa Scientific Research Grant (to K. M.) and Yamaguchi University under the YU Strategic Program for Fostering Research Activities (2010-2011, 2013-2014).

\section{References}

1. Zimmerman, J.; Halloway, A.; Sibi, M. P. Free Radical Cyclization Reactions. In Handbook of Cyclization Reactions; Ma, S., Ed.; Wiley-VCH: Weinheim, Germany, 2010; Vol. 2, pp 1099-1148.

2. Majumdar, K. C.; Mukhopadhyay, P. P.; Basu, P. K. Heterocycles 2004, 63, 1903. doi:10.3987/REV-04-577

3. Majumdar, K. C.; Basu, P. K.; Mukhopadhyay, P. P. Tetrahedron 2004, 60, 6239. doi:10.1016/j.tet.2004.05.001

4. Majumdar, K. C.; Basu, P. K.; Mukhopadhyay, P. P. Tetrahedron 2005, 61, 10603. doi:10.1016/j.tet.2005.07.079

5. Ishibashi, H. Chem. Rec. 2006, 6, 23-31. doi:10.1002/tcr.20069

6. Barrero, A. F.; Quilez del Moral, J. F.; Sanchez, E. M.; Arteaga, J. F. Eur. J. Org. Chem. 2006, 1627. doi:10.1002/ejoc.200500849

7. Majumdar, K. C.; Basu, P. K.; Chattopadhyay, S. K. Tetrahedron 2007, 63, 793. doi:10.1016/j.tet.2006.09.049

8. Yoshioka, E.; Kohtani, S.; Miyabe, H. Heterocycles 2009, 79, 229. doi:10.3987/REV-08-SR(D)8

9. Rowlands, G. J. Tetrahedron 2010, 66, 1593. doi:10.1016/j.tet.2009.12.023

10. Galli, C. Chem. Rev. 1988, 88, 765. doi:10.1021/cr00087a004

11. Curran, D. P.; Kim, D.; Liu, H. T.; Shen, W. J. Am. Chem. Soc. 1988, 110, 5900. doi:10.1021/ja00225a052

12. Snieckus, V.; Cuevas, J.-C.; Sloan, C. P.; Liu, H.; Curran, D. P J. Am. Chem. Soc. 1990, 112, 896. doi:10.1021/ja00158a075

13. Dènés, F.; Beaufils, F.; Renaud, P. Synlett 2008, 2389. doi:10.1055/s-2008-1078016

14. Chatgilialoglu, C.; Newcomb, M. Adv. Organomet. Chem. 1999, 44, 67. doi:10.1016/S0065-3055(08)60620-6

See for a review om tin hydride and related hydride reagents.
15. Kamimura, A.; Ishikawa, S.; Noguchi, F.; Moriyama, T.; So, M.; Murafuji, T.; Uno, H. Chem. Commun. 2012, 48, 6592. doi:10.1039/c2cc31753b

16. Kamimura, A.; Miyazaki, K.; Yamane, Y.; Yo, R.; Ishikawa, S.; Uno, H. submitted.

17. Gilman, H.; Atwell, W. H.; Sen, P. K.; Smith, C. L.

J. Organomet. Chem. 1965, 4, 163. doi:10.1016/S0022-328X(00)84384-3

18. Chatgilialoglu, C. Chem.-Eur. J. 2008, 14, 2310. doi:10.1002/chem.200701415

19. Kanabus-Kaminska, J. M.; Hawari, J. A.; Griller, D.; Chatgilialoglu, C. J. Am. Chem. Soc. 1987, 109, 5267. doi:10.1021/ja00251a035

20. Chatgilialoglu, C.; Griller, D.; Lesage, M. J. Org. Chem. 1988, 53, 3641. doi:10.1021/jo00250a051

21. Chatgilialoglu, C. Acc. Chem. Res. 1992, 25, 188. doi:10.1021/ar00016a003

22. Chatgilialoglu, C. Organosilanes in Radical Chemistry; Wiley: Chichester (UK), 2004. doi:10.1002/0470024755

23. Miura, K.; Oshima, K.; Utimoto, K. Chem. Lett. 1992, 21, 2477. doi:10.1246/cl.1992.2477

24. Miura, K.; Oshimaa, K.; Utimoto, K. Bull. Chem. Soc. Jpn. 1993, 66, 2348. doi:10.1246/bcsj.66.2348

25. Kulicke, K.; Chatgilialoglu, C. S.; Kopping, B.; Giese, B. Helv. Chim. Acta 1992, 75, 935. doi:10.1002/hlca.19920750327

26. Studer, A. Angew. Chem., Int. Ed. 1998, 37, 462. doi:10.1002/(SICI)1521-3773(19980302)37:4<462::AID-ANIE462>3.0. $\mathrm{CO} ; 2-\mathrm{M}$

27. Studer, A.; Steen, H. Chem.-Eur. J. 1999, 5, 759. doi:10.1002/(SICI)1521-3765(19990201)5:2<759::AID-CHEM759>3.0. $\mathrm{CO} ; 2-\mathrm{V}$

28. Rouquet, G.; Robert, F.; Méreau, R.; Castet, F.; Renaud, P.; Landais, Y. Chem.-Eur. J. 2012, 18, 940. doi:10.1002/chem.201102318

29. Kamimura, A.; Okawa, H.; Morisaki, Y.; Ishikawa, S.; Uno, H. J. Org. Chem. 2007, 72, 3569. doi:10.1021/jo062251h

30. Ishikawa, S.; Noguchi, F.; Kamimura, A. J. Org. Chem. 2010, 75, 3578. doi:10.1021/jo100315j

31. Crystallographic data (excluding structure factors) for the structures of trans 2a have been deposited with the Cambridge Crystallographic Data Centre under supplementary publication numbers CCDC 931894 Copies of the data can be obtained, free of charge, upon request from the CCDC, 12 Union Road, Cambridge CB2 1EZ, UK [fax: +44(0)-1223-336033 or email: deposit@ccdc.cam.ac.uk]. 


\section{License and Terms}

This is an Open Access article under the terms of the Creative Commons Attribution License

(http://creativecommons.org/licenses/by/2.0), which permits unrestricted use, distribution, and reproduction in any medium, provided the original work is properly cited.

The license is subject to the Beilstein Journal of Organic Chemistry terms and conditions:

(http://www.beilstein-journals.org/bjoc)

The definitive version of this article is the electronic one which can be found at:

doi:10.3762/bjoc.9.149 